\title{
A new species, Lophiostoma versicolor, from Japan (Pleosporales, Dothideomycetes)
}

\author{
Hirayama $\mathrm{K}^{1}$, Hashimoto $\mathrm{A}^{2,3}$ and Tanaka $\mathrm{K}^{2}$ \\ ${ }^{1}$ Apple Experiment Station, Aomori Prefectural Agriculture and Forestry Research Center, 24 Fukutami, Botandaira, \\ Kuroishi, Aomori 036-0332, Japan \\ ${ }^{2}$ Faculty of Agriculture and Life Sciences, Hirosaki University, 3 Bunkyo-cho, Hirosaki, Aomori, 036-8561, Japan \\ ${ }^{3}$ The United Graduate School of Agricultural Sciences, Iwate University, 18-8 Ueda 3 chome, Morioka 020-8550, \\ Japan
}

Hirayama K, Hashimoto A, Tanaka K 2014 - A new species, Lophiostoma versicolor, from Japan (Pleosporales, Dothideomycetes). Mycosphere 5(3), 411-417, Doi 10.5943/mycosphere/5/3/3

\begin{abstract}
Lophiostoma versicolor sp. nov. was found on Acer sp. in Japan. This species is characterized by ascomata with a laterally compressed apex; clavate, 2(-4)-spored asci with a long stipe; and verruculose, 3-septate, versicolored ascospores without a sheath or appendages. Phylogenetic analyses based on LSU nrDNA sequences supported the generic placement and species validity of $L$. versicolor.
\end{abstract}

Key words - ITS - Lophiostomataceae - Lophiotrema - LSU nrDNA - Pleosporomycetidae Systematics - Taxonomy

\section{Introduction}

During an investigation of bitunicate ascomycetes in Japan, an unidentified fungus was found on dead twigs of Acer sp. The morphological characteristics of the fungus, such as the presence of ascomata with a compressed beak and clavate asci, recall those of Lophiostoma (Hirayama \& Tanaka 2011) belonging to the Lophiostomataceae. This fungus, however, is different from any of the existing species of the genus because it possesses 2(-4)-spored asci and verruculose, 3 -septate, versicolored ascospores without a sheath or appendages.

As a generic placement of our obtained fungus, Lophiotrema was also considered. This genus is morphologically similar to Lophiostoma. For example, they share several characteristics including their carbonaceous ascomata with a laterally compressed apex (termed as a crest-like beak with a slit-like ostiole), fissitunicate asci, and hyaline to dark brown, uni- to multiseptate ascospores (Holm \& Holm 1988). Some authors treated Lophiotrema as a synonym of the older genus Lophiostoma (Chesters \& Bell 1970, Leuchtmann 1985), whereas most authors regarded them as distinct but closely related genera within Lophiostomataceae on the basis of morphological observations (Barr 1992, Yuan \& Zhao 1994, Tanaka \& Harada 2003a, b).

Hirayama \& Tanaka (2011) revealed that Lophiostoma and Lophiotrema are distinct genera belonging to Lophiostomataceae and Lophiotremataceae, respectively, based on phylogenetic analyses of small subunit (SSU) and large subunit (LSU) nuclear ribosomal DNA (nrDNA) sequences. They concluded that the ascus shape including the length of the ascus stipe is the most important morphological criterion to delineate both genera. In Lophiostoma, the asci are clavate 
with a relatively long stipe [mostly (10-)15-30 $\mu \mathrm{m}$ long], whereas in Lophiotrema, the asci are cylindrical with a short stipe (up to $15 \mu \mathrm{m}$ long; Hirayama \& Tanaka 2011). According to these generic circumscriptions, the collected fungus might appear to be a member of Lophiostoma because it has clavate asci with a relatively long stipe.

The objectives of this study were to evaluate the taxonomic significance of ascus shape and ascus stipe length which were used to distinguish both genera (Hirayama \& Tanaka 2011) using the newly obtained fungus and to confirm its species validity based on phylogenetic analyses of LSU sequences.

\section{Materials \& Methods}

\section{Isolates and morphology}

The methods for microscopy and single spore isolation followed those described by Hirayama et al. (2010). For the ascospore septum position, the decimal system (Shoemaker 1984) was used. The holotype specimen was deposited in the Herbarium of Hirosaki University (HHUF). The growth rate and colony characteristics were recorded from cultures grown on corn meal agar (CMA, Difco), malt extract agar (MEA, Difco), and potato dextrose agar (PDA, Difco) after 3 weeks at $20^{\circ} \mathrm{C}$ in the dark. Colors were designated as described by Kornerup \& Wanscher (1978). To validate isolations, sporulation was promoted by placing a small piece of mycelial culture on rice straw agar (RSA; Tanaka \& Harada 2003a). The utilized fungal culture was deposited in the National Institute of Agrobiological Sciences (MAFF).

\section{Phylogenetic analyses}

The detailed methods of DNA extraction and polymerase chain reaction (PCR) amplification were as those described by Tanaka et al. (2009). Partial LSU nrDNA and complete internally transcribed spacers (ITS) of nrDNA were amplified by PCR using the primer pairs LR0R-LR7 for LSU (Rehner \& Samuels 1994) and ITS1-ITS4 for ITS (White et al. 1990). Newly obtained sequences were deposited in GenBank.

A BLAST search using the LSU sequence of the newly obtained taxon suggested that it is a member of Lophiostoma rather than Lophiotrema. Therefore, phylogenetic analyses of the collected fungus (Lophiostoma versicolor) with other Lophiostoma spp. were performed. The obtained LSU sequence of L. versicolor was manually aligned along with published sequences of Lophiostoma (e.g., Tanaka \& Hosoya 2008, Mugambi \& Huhndorf 2009, Suetrong et al. 2009, Zhang et al. 2009a, b, Hirayama \& Tanaka 2011) in GenBank using the MUSCLE algorithm implemented in the program Molecular Evolutionary Genetic Analysis (MEGA) v5 (Tamura et al. 2011). Sequences of Preussia terricola and Westerdykella angulata, both members of Sporormiaceae (Kruys \& Wedin 2009), were used as outgroup taxa. The aligned dataset was subjected to two phylogenetic analyses involving maximum likelihood (ML) and maximum parsimony (MP) using MEGA 5. Based on the Bayesian information criterion of MEGA 5, Kimura 2-parameter model with gamma distribution $(\mathrm{K} 2+\mathrm{G})$ was selected for the ML analysis. The ML tree was obtained using the default settings with "use all site" for gaps/missing data treatment. MP tree was generated using the close-neighbor-interchange heuristic search (level 1), the initial tree by random addition sequence (100 replicates), and the "use all site" option. The confidence in topologies was assessed using a bootstrap (BS) test involving 1000 replicates. The ITS sequence of $L$. versicolor was also obtained as a DNA barcode maker (Schoch et al. 2012), and it was not used for phylogenetic analysis.

\section{Results}

\section{Phylogenetic analyses}

A total of 37 LSU sequences of Lophiostoma spp. were aligned with outgroup taxa. Of 1228 characters, $143(11.6 \%)$ were variable and $100(8.1 \%)$ were parsimony-informative. The ML tree 


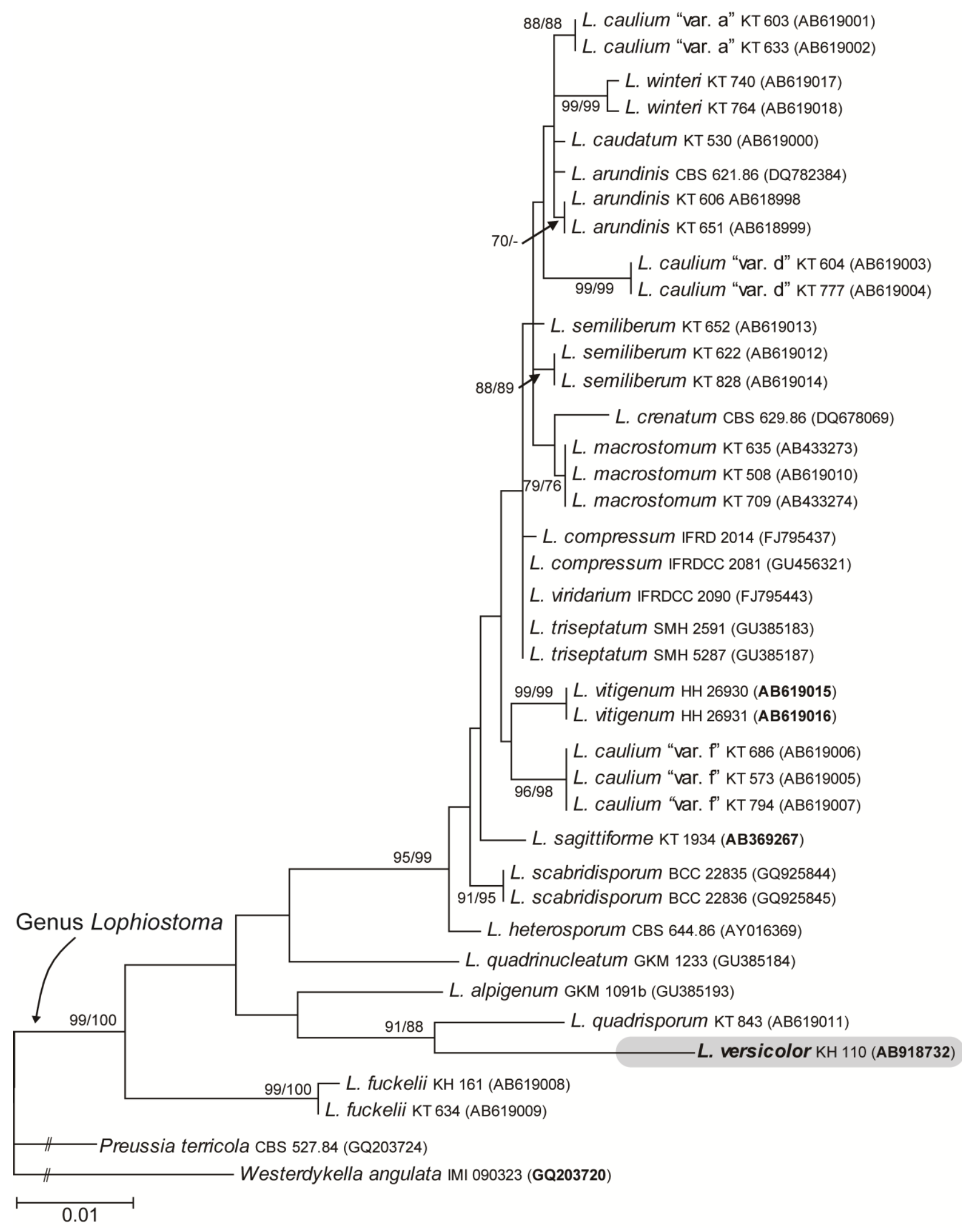

Fig. 1 - The ML tree of Lophiostoma spp. with the highest log likelihood (-3081.8178) based on the LSU dataset (1228 positions). ML and MP BS values greater than $70 \%$ are indicated at the nodes. A hyphen indicates BS values lower than $70 \%$. The isolate number and GenBank accession number (in parentheses) are noted after the species name. Sequence derived from the type is shown in bold. The tree was rooted with Preussia terricola and Westerdykella angulata (Sporormiaceae). 
with the highest log likelihood (-3081.8178) is shown in Fig. 1. The topology of the MP tree was almost identical to that of the ML tree. The newly obtained fungus (L. versicolor) nested within the strongly supported clade of Lophiostoma, which had high BS values (99\% in ML, 100\% in MP; Fig. 1). Phylogenetically, L. versicolor was most closely related to $L$. quadrisporum, and their relationship was moderately supported (91\% in ML, 88\% in MP; Fig. 1). These two species were sister taxa to L. alpigenum, but without support.

\section{Taxonomy}

Lophiostoma versicolor K. Hiray. \& Kaz. Tanaka, sp. nov.

Figs. 2-18 MycoBank: MB 808363.

Etymology - in reference to the versicolored ascospores.

Holotype: HHUF 30448.

Ascomata 330-350 $\mu \mathrm{m}$ high, 360-400 $\mu \mathrm{m}$ diam., scattered, immersed, erumpent at beak, subglobose, black. Beak $170 \mu \mathrm{m}$ wide, crest-like, composed of globose, 2-4 $\mu \mathrm{m}$ diam., thickwalled cells, with a slit-like ostiole. Ascomatal wall 20-27.5 $\mu \mathrm{m}$ thick at sides, composed of 5-7 layers of rectangular, 7-10 $\times 2.5-6 \mu \mathrm{m}$, thin-walled cells, poorly developed at the base. Pseudoparaphyses numerous, 1-2 $\mu \mathrm{m}$ wide, septate, hyaline, branched and anastomosed, associated with gelatinous material. Asci 60-67.5(-77.5) $\times 10-12.5(-15) \mu \mathrm{m}$, fissitunicate, clavate, with a stalk of 12.5-22.5(-27.5) $\mu \mathrm{m}$ long, rounded at the apex, with an ocular chamber, with 2(-4) overlapping uni- or bi-seriate ascospores. Ascospores 18-23 ×6-9 $\mu \mathrm{m}$ (mean $20.2 \times 7.7 \mu \mathrm{m}, \mathrm{n}=$ 30 ), L/W 2.3-2.9 (mean 2.6, $\mathrm{n}=30$ ), broadly fusiform, straight, with a primary septum median to submedian $(0.50-0.55$; mean $0.51, \mathrm{n}=30)$, 3-septate, constricted at primary septum, versicolored, brown to reddish brown except pale end cells, verruculose, guttulate, without sheath or appendage.

Colonies on CMA $13 \mathrm{~mm}$ after 3 weeks at $20^{\circ} \mathrm{C}$ in the dark, Pastel Gray (1C1: Kornerup \& Wanscher 1978), reverse Olive Gray (2F2). On MEA $11 \mathrm{~mm}$, Olive Gray (2E2), reverse Olive Gray (1F2). On PDA 15 mm, Medium Gray (1D1) reverse Pastel Gray (1C1). No pigment was produced on these media. On RSA ascomatal state almost identical with those on the natural specimen was observed. Ascospores 19-22 × 6-7 $\mu$ m (mean $20.8 \times 6.5 \mu \mathrm{m}, \mathrm{n}=50$ ), L/W 2.9-3.7 (mean 3.2, $\mathrm{n}=50$ ).

Asexual state - unknown.

Known distribution - Japan.

Material examined - Japan, Mie, Tsu, Campus of Mie Univ., on twigs of Acer sp., 30 May 2008, coll. K. Tanaka and H. Yonezawa, KH 110 (HHUF 30448 holotype designated here) - extype culture MAFF 244508.

nrDNA sequences - AB918731 (ITS), AB918732 (LSU).

\section{Discussion}

Lophiostoma, typified by L. macrostomum, belongs to Lophiostomataceae, Pleosporales, Dothideomycetes (Kirk et al. 2008, Zhang et al. 2012, Hyde et al. 2013). Species of this genus are found on various plants, e.g. woody plants, reeds, palms and bamboo, they and are inhabitants of terrestrial, freshwater and marine environments. This genus is characterized by ascomata with a laterally compressed apex, fissitunicate asci, and hyaline to dark brown, uni- to multiseptate ascospores (Holm \& Holm 1988, Hirayama \& Tanaka 2011). These ecological and morphological features are similar to those of Lophiotrema. Therefore, they have been considered as closely related genera belonging to the same family (Barr 1992) or congeneric (Chesters \& Bell 1970). Recently, a molecular study of Lophiostoma and Lophiotrema revealed that they are phylogenetically distinct genera, and Lophiotrema is related to Testudinaceae rather than Lophiostomataceae (Zhang et al. 2009a, b). More recently, Hirayama \& Tanaka (2011) concluded that these genera can be mainly distinguished by ascus shape including its stipe length, for example, clavate asci with a relatively long stipe [mostly $(10-) 15-30 \mu \mathrm{m}$ ] in Lophiostoma and cylindrical 


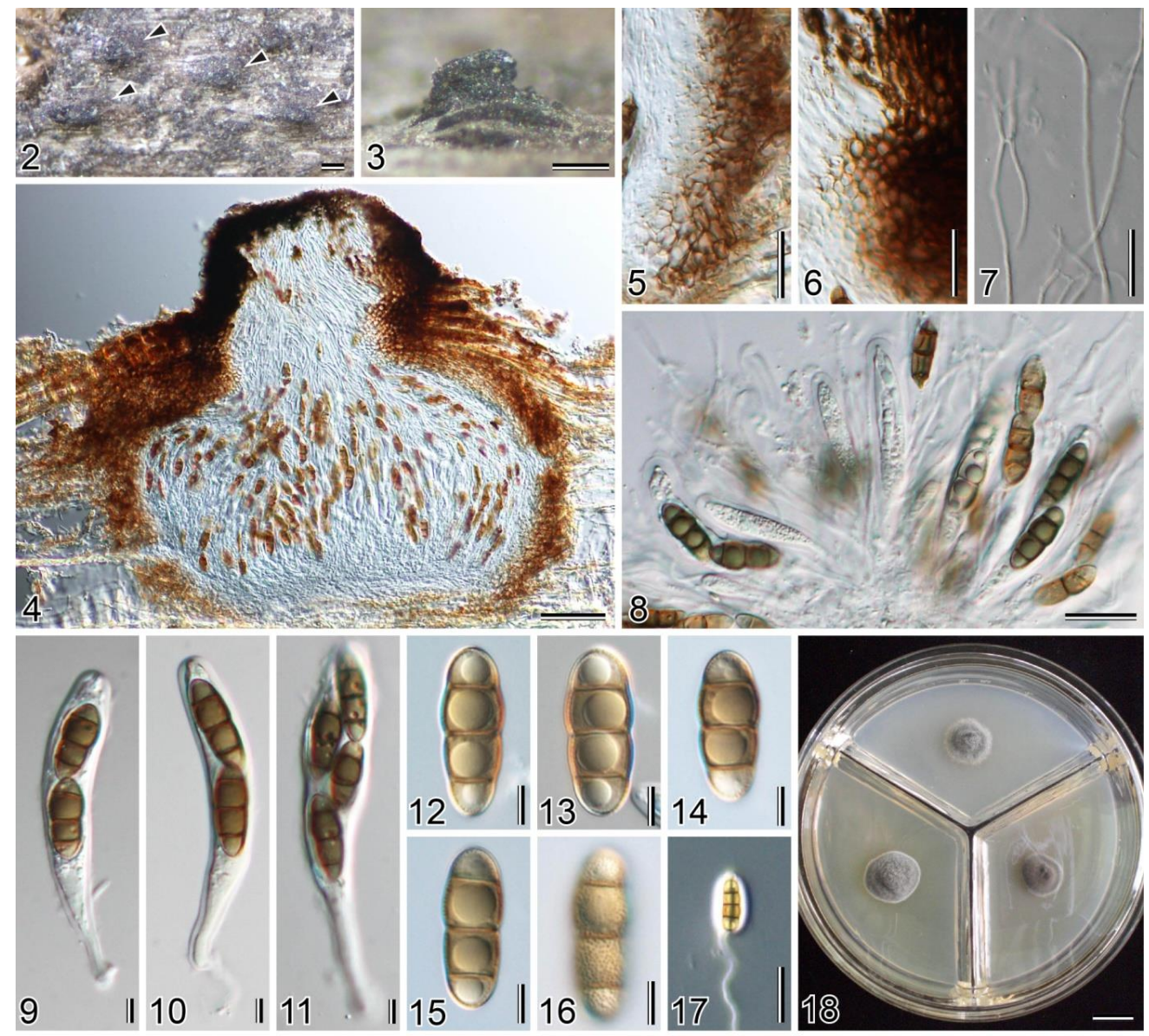

Figs 2-18 - Lophiostoma versicolor (2-17 from HHUF 30448. 18 from MAFF 244508). 2 Ascomata on host surface. 3 Compressed beak of ascoma, 4 Longitudinal section of ascoma. 5 Ascomatal wall at side. 6 Wall of beak. 7 Pseudoparaphyses. 8 Pseudoparaphyses and asci. 9-11 Asci. 12-16 Ascospores (16 Ascospore with verruculose ornamentation). 17 Germinating ascospore. 18 Colonies on CMA (upper), PDA (left) and MEA (right) after 3 weeks at $20^{\circ} \mathrm{C}$ in the dark. - Bars $2,3=200 \mu \mathrm{m} .4=50 \mu \mathrm{m} .5-8,17=20 \mu \mathrm{m} .9-16=5 \mu \mathrm{m} .18=1 \mathrm{~cm}$.

asci with a short stipe (up to $15 \mu \mathrm{m}$ ) in Lophiotrema, and they established a new family Lophiotremataceae for Lophiotrema.

The collected fungus from Acer sp. has ascomata with a laterally compressed beak with a slit-like ostiole and clavate asci with a long stipe (Figs. 2, 3, 8). These morphological characteristics of this fungus suggest that it is a member of Lophiostoma, but it also has unusual features for the genus. For example, 2(-4)-spored asci and verruculose, 3-septate, versicolored ascospores without a sheath or appendages (Figs. 9-16) are atypical for this genus and there are no species with these characteristics in the monographs of Lophiostoma (e.g., Lehmann 1886, Berlese 1894, Chesters \& Bell 1970, Holm \& Holm 1988, Barr 1992, Yuan \& Zhao 1994, Tanaka \& Harada 2003a). Lophiotrema, morphologically closest genus to Lophiostoma, was also considered as a generic placement of the fungus. Therefore, molecular studies were conducted to confirm the generic classification of the collected fungus.

Preliminary analysis based on a BLAST search using LSU sequences, as well as those of ITS obtained for barcoding, suggested that the new species belongs to Lophiostoma rather than Lophiotrema. Subsequent phylogenetic analyses based on LSU nrDNA sequences for the obtained fungus (L. versicolor) and Lophiostoma spp. clearly indicated that L. versicolor is a member of Lophiostoma (Fig. 1). The characteristic versicolored ascospores observed in L. versicolor are known in Byssothecium (Boise 1983) and in Passeriniella (Berlese 1894), but these genera belong to the Massarinaceae (Zhang et al. 2012, Hyde et al. 2013) and to an unknown lineage comprising 
marine fungi (Suetrong et al. 2009), respectively. Lophiostoma species including L. versicolor formed a monophyletic clade supported by strong BS values (99-100\%; Fig. 1). Lophiostoma versicolor was most close to L. quadrisporum (similarity 978/1009 $=96.9 \%$ in LSU), and their relationship had moderate BS support (88-91\%; Fig. 1). These results reconfirmed that the ascus shape including the length of ascus stipe, which was previously proposed for differentiating Lophiostoma and Lophiotrema (Hirayama \& Tanaka 2011), is a reliable taxonomic indicator for distinguishing these genera.

Lophiostoma versicolor has several unique characteristics such as 2(-4)-spored asci and verruculose, versicolored ascospores (Figs. 8-16). Versicolored ascospores similar to those of $L$. versicolor are known to be present in L. pileatum, but this species differs from $L$. versicolor in having 8-spored asci and 6-10-septate, larger ascospores [(35-)40-60(-67) $\times 12-30 \mu \mathrm{m}$; Chesters \& Bell 1970]. Most species of Lophiostoma have 8-spored asci, whereas species that have 2- or 4spored asci are extremely rare. Lophiostoma quadrisporum, which is phylogenetically close to $L$. versicolor (Fig. 1), has 4-spored asci, but it has 1-septate, smooth, hyaline ascospores (Tanaka \& Harada 2003b, misidentified as L. nucula, see also Hirayama \& Tanaka 2011). The asci of $L$. macrostomoides and L. mucosum are (4-)8-spored, but the former has (4-)5-7(-8)-septate ascospores (Mathiassen 1993) and the latter has more large-sized ascospores, (27.5-)30.5-40(46.5) $\times(5.5-) 7-10.5(-12) \mu \mathrm{m}$ (Tanaka \& Harada 2003a), as compared to those of L. versicolor. Generally, the number of ascospores per ascus is considered as an important character for species discrimination (Voglmayr \& Jaklitsch 2011). Therefore, we described here the fungus as a new species of Lophiostoma, L. versicolor.

\section{Acknowledgements}

This work was partially supported by funding from the Japan Society for the Promotion of Science (JSPS, 25440199) and a Hirosaki University Grant for Exploratory Research by Young Scientists (2008-2013). We thank H. Yonezawa for helping with the collection of fungal specimen.

\section{References}

Barr ME. 1992 - Notes on the Lophiostomataceae (Pleosporales). Mycotaxon 45, 191-221.

Berlese AN. 1894 - Icones fungorum omnium hucusque cognitorum. Vol. 1 (Reprint 1968, Bibliotheca Mycologia 16A, 1-243).

Boise J. 1983 - On Trematosphaeria circinans and reinstatement of the genus Byssothecium. Mycologia 75, 666-669.

Chesters CGC, Bell A. 1970 - Studies in the Lophiostomataceae. Mycological Papers 120, 1-129.

Hirayama K, Tanaka K, Raja HA, Miller AN, Shearer CA. 2010 - A molecular phylogenetic assessment of Massarina ingoldiana sensu lato. Mycologia 102, 729-746.

Hirayama K, Tanaka K. 2011 - Taxonomic revision of Lophiostoma and Lophiotrema based on reevaluation of morphological characters and molecular analyses. Mycoscience 52, 401-412.

Holm L, Holm K. 1988 - Studies in the Lophiostomataceae with emphasis on the Swedish species. Symbolae Botanicae Upsalienses 28 (2), 1-50.

Hyde KD, Jones EBG, Liu JK, Ariyawansa H, Boehm E, Boonmee S, Braun U, Chomnunti P, Crous PW, Dai DQ, Diederich P, Dissanayake A, Doilom M, Doveri F, Hongsanan S, Jayawardena R, Lawrey JD, Li YM, Liu YX, Lücking R, Monkai J, Muggia L, Nelsen MP, Pang KL, Phookamsak R, Senanayake IC, Shearer CA, Suetrong S, Tanaka K, Thambugala KM, Wijayawardene NN, Wikee S, Wu HX, Zhang Y, Aguirre-Hudson B, Alias SA, Aptroot A, Bahkali AH, Bezerra JL, Bhat DJ, Camporesi E, Chukeatirote E, Gueidan C, Hawksworth DL, Hirayama K, Hoog SD, Kang JC, Knudsen K, Li WJ, Li XH, Liu ZY, Mapook A, McKenzie EHC, Miller AN, Mortimer PE, Phillips AJL, Raja HA, Scheuer C, Schumm F, Taylor JE, Tian Q, Tibpromma S, Wanasinghe DN, Wang Y, Xu JC, Yacharoen S, Yan JY, Zhang M. 2013 - Families of Dothideomycetes. Fungal Diversity 63, 1-313.

Kirk PM, Cannon PF, Minter DW, Stalpers JA. 2008 - Ainsworth and Bisby's Dictionary of the 
Fungi, 10th edn. CAB International, Wallingford.

Kornerup A, Wanscher JH. 1978 - Methuen handbook of colour, 3th edn. Methuen, London.

Kruys Å, Wedin M. - 2009 Phylogenetic relationships and an assessment of traditionally used taxonomic characters in the Sporormiaceae (Pleosporales, Dothideomycetes, Ascomycota), utilising multi-gene phylogenies. Systematics and Biodiversity 7, 465-478.

Lehmann F. 1886 - Systematische Bearbeitung der Pyrenomycetengattung Lophiostoma (Fr.) Ces. \& Dntrs., mit Beru"cksichtigung der verwandten Gattungen Glyphium, (N.i.c.), Lophium, Fr., und Mytilinidion, Duby. Nova Acta 50, 47-152.

Leuchtmann A. 1985 - Kulturversuche mit einigen Arten der Gattung Lophiostoma Ces. \& De Not. Sydowia 38, 158-170.

Mathiassen G. 1993 - Corticolous and lignicolous Prenomycetes s. lat. (Ascomycetes) on Salix along a mid-Scandinavian transect. Sommerfelita 20, 1-180.

Mugambi GK, Huhndorf SM. 2009 - Molecular phylogenetics of Pleosporales: Melanommataceae and Lophiostomataceae re-circumscribed (Pleosporomycetidae, Dothideomycetes, Ascomycota). Studies in Mycology 64, 103-121.

Rehner SA, Samuels GJ. 1994 - Taxonomy and phylogeny of Gliocladium analysed from nuclear large subunit ribosomal DNA sequences. Mycological Research 98, 625-634.

Schoch CL, Seifert KA, Huhndorf S, Robert V, Spougea JL, Levesqueb CA, Chenb W, Fungal Barcoding Consortium. 2012 - Nuclear ribosomal internal transcribed spacer (ITS) region as a universal DNA barcode marker for Fungi. Proceedings of the National Academy of Sciences of the United States of America 109, 6241-6246.

Shoemaker RA. 1984 - Canadian and some extralimital Nodulosphaeria and Entodesmium species. Canadian Journal of Botany 62, 2730-2753.

Suetrong S, Schoch CL, Spatafora JW, Kohlmeyer J, Volkmann-Kohlmeyer B, Sakayaroj J, Phongpaichit S, Tanaka K, Hirayama K, Jones EBG. 2009 - Molecular systematics of the marine Dothideomycetes. Studies in Mycology 64, 155-173.

Tamura K, Peterson D, Peterson N, Stecher G, Nei M, Kumar S. 2011 - MEGA5: molecular evolutionary genetics analysis using maximum likelihood, evolutionary distance, and maximum parsimony methods. Molecular Biology and Evolution 28, 2731-2739.

Tanaka K, Harada Y. 2003a - Pleosporales in Japan (1): the genus Lophiostoma. Mycoscience 44, 85-96.

Tanaka K, Harada Y. 2003b - Pleosporales in Japan (2): Lophiotrema. Mycoscience 44, 115-121.

Tanaka K, Hirayama K, Yonezawa H, Hatakeyama S, Harada Y, Sano T, Shirouzu T, Hosoya T. 2009 - Molecular taxonomy of bambusicolous fungi: Tetraplosphaeriaceae, a new pleosporalean family with Tetraploa-like anamorphs. Studies in Mycology 64, 175-209.

Tanaka K, Hosoya T. 2008 - Lophiostoma sagittiforme sp. nov., a new ascomycete (Pleosporales, Dothideomycetes) from Island Yakushima in Japan. Sydowia 60, 131-145.

Voglmayr H, Jaklitsch WM. 2011 - Molecular data reveal high host specificity in the phylogenetically isolated genus Massaria. Fungal Diversity 46, 133-170.

White TJ, Bruns T, Lee S, Taylor J. 1990 - Amplification and direct sequencing of fungal ribosomal RNA genes for phylogenetics. In: Innis MA, Gelfand DH, Sninsky JJ, White TJ (eds) PCR protocols: a guide to methods and applications, pp 315-322, Academic Press, San Diego.

Yuan Z, Zhao Z. 1994 - Studies on lophiostomataceous fungi from Xinjianf, China. Sydowia 46, 162-184.

Zhang Y, Schoch CL, Fournier J, Crous PW, De Gruyter J, Woudenberg JHC, Hirayama K, Tanaka K, Pointing SB, Spatafora JW, Hyde KD. 2009a - Multi-locus phylogeny of Pleosporales: a taxonomic, ecological and evolutionary reevaluation. Studies in Mycology 64, 85-102.

Zhang Y, Wang HK, Fournier J, Crous PW, Jeewon R, Pointing SB, Hyde KD. 2009b - Towards a phylogenetic clarification of Lophiostoma/Massarina and morphologically similar genera in the Pleosporales. Fungal Diversity 38, 225-251.

Zhang Y, Crous PW, Schoch CL, Hyde KD. 2012 - Pleosporales. Fungal Diversity 53, 1-221. 